\title{
Behind Closed Doors?
}

\section{The Private Lives of the Minor Communist Party Activists in Romania, 1945-1960}

\author{
Cristina Diac
}

\begin{abstract}
This article explores the relationship between men, spousal violence, and politics in Romania in the 1950s and aims to analyze how the Romanian Communist Party (RCP), as an institution, dealt with spousal violence perpetrated by its officials. The RCP was a significant player within state socialist regime. Thus, the way the Party managed the discussed cases of spousal violence gives an idea about how gender relations functioned in reality, beyond the official discourse and the letter of the law. This article argues that spousal violence was the result of inequality within the family and a manifestation of patriarchy and male dominance. This analysis draws on files from the archive of the Committee of Party Control of the Central Committee of the RCP, which contains cases of Party members with a history of spousal violence.
\end{abstract}

KeYwORDs: masculinity, patriarchy, Romania, spousal violence, state socialism

M. M. married P. R. in March 1953 after a one-year courtship. Both were born in the rural side of the Prahova oil region, to families whose fathers were factory workers and mothers were housewives. The couple met in Brașov when M. M. was twenty-two years old and was studying to become an engineer. His future wife was three years younger and was studying at a technical school in the same Transylvanian city. In 1952, immediately after she met M. M., the young woman gave up her studies and, by implication, the possibility of a better career and took a job at the Steagul Roșu (Red flag) Plant in Brașov to support her fiancé financially during his university studies. The young couple began their sexual life before marriage, and P. R. got pregnant and gave birth to a child, adopted by some relatives when the baby was three weeks old. The parents did not explain this decision in 1959 when their personal life come under Party scrutiny. In those circumstances, M. M. stated instead that he had married "out of ambition" because P. R.'s family thought he was not good enough for their 
daughter. Although under the age of twenty-one and needing her father's consent, the young woman married M. M. just a few months before the Family Code of 1954 entered into force, a Code that granted women the right to marry without the consent of their fathers.

The newlyweds lived together for only six months. In the autumn of 1953, M. M. transferred to Polytechnic University in Bucharest. His wife was transferred to the Boldeşti oil well, residing with her in-laws in the adjacent commune of Scăeni. ${ }^{1}$ M. M. graduated in June 1956, specializing in machinery and machinery construction, and was hired as a mechanical engineer by the People's Council of Ploiești. In April 1957, he also became a member of the Romanian Communist Party (RCP). It was likely that the social status he had achieved through his education and party membership helped the engineer solve his housing issue: in May 1957, one month after M. M. had become a Party member, the couple obtained an apartment and moved to Ploiesti.

His wife continued to commute to Boldești for work for another year. In 1958, she was transferred to the Ploiești Agrozootechnic Regional Enterprise. She may have wanted a job closer to home. Or the transfer might have been part of a broader strategy to save her marriage: in the same year, M. M. entered into a serious extramarital relationship with a co-worker. When his wife reproached him for his infidelity, "she was terrorized and slapped."2

M. M.'s Party file contains all these details about his life. This source offers insight into the problems of a typical couple in socialist Romania, as well as the procedures triggered by the RCP to deal with the private lives of its members. It also enhances our understanding of gender politics in Romania in the 1950s and how the couples featured in this case understood gender norms and gender roles.

This article explores the relationship between men, spousal violence, and politics in Romania in the 1950s, and it aims to analyze how the RCP dealt with spousal violence perpetrated by its officials. It suggests that spousal violence was the result of the patriarchal ideology of male supremacy within the family. This article draws on files from the archive of the Committee of Party Control (CPC) of the Central Committee of the RCP that contain cases of Party activists with a history of spousal violence.

Many terms have been used to define violence in couples: domestic violence, spousal violence, spousal abuse, family violence, men's violence against women, intimate partner violence. ${ }^{3}$ Because domestic violence and family violence also can denote violence among family members (including siblings and parent-child violence either way), violence by women against male partners, and between same-sex sexual partners, ${ }^{4}$ this article uses the term spousal violence. Spousal violence is understood as any physical aggression (hit with a fist or an object, slap, shake, or kick) applied by a man to his wife, "accompanied by a wide range of other abusive, controlling and harmful behaviors," all meant "to assert power and authority or to restore them when they are perceived to be breaking down." 5

The issue of spousal violence during the state socialist regimes of Eastern Europe is difficult to research. In the Soviet Union, the incidence of spousal violence is impossible to estimate during much of the Soviet period, primarily because the state refused to publish statistics concerning this matter, claiming that crime rates were decreasing and many forms of crime did not exist at all. ${ }^{6}$ Psychologist Sharon Horne explains 
that the underreporting was ideologically motivated: to admit that women were being beaten or killed by their husbands meant to admit that domestic abuse occurred not only in capitalist systems but also in communist systems. ${ }^{7}$ Jill Massino noted that no statistics were compiled on domestic violence in socialist Romania, either. ${ }^{8}$

In Birth of Democratic Citizenship, Maria Bucur and Mihaela Miroiu examine the Romanian women's road toward democratic citizenship over the last seventy years. They noted that during the 1950s, the state socialist regime codified equal personhood for women within marriage (in 1954), granted women property and political rights, and their reproductive freedom (between 1957 and 1966). Thus, the state socialist regime took important steps to legalize women's equality and autonomy. Bucur and Miroiu addressed the issue of spousal violence as well and note that their respondents, 101 women from the Hunedoara region, talked about domestic violence only "on the rare occasions." When the interviewees touched on this issue, "they generally did so in the third person" and rarely shared details. ${ }^{9}$ Jill Massino makes a similar point: her respondents also touched on the issue of spousal violence only obliquely. The victims of spousal violence refused to remember and discuss abuse because of the social stigma and shame surrounding it. Analyzing the content of Femeia (Woman), the magazine published by the National Council of Women in socialist Romania, Massino noticed that this publication occasionally took up the issue of spousal violence and deduced that it was pervasive enough that it could not simply be ignored, but required media acknowledgment. The high incidence of domestic violence in Romania since 1989, Massino emphasized, allows us to presume that it was by no means uncommon during the socialist period. ${ }^{10}$

Luciana Jinga has assessed the phenomenon of spousal violence in state-socialist Romania from the victims' perspectives, employing the concepts of structural and symbolic violence. Investigating the issue of spousal violence after 1966, Jinga traces a line of continuity from the interwar period through the present. This continuity, she remarks, is based on and supported by a set of complex mechanisms and patriarchal beliefs deeply rooted in the collective Romanian mentality. Jinga concludes that wife-beating is a culturally accepted family practice "and even perceived as normal by a majority of people in Romania,"11 a practice whose roots can be traced back to the state socialism period and even before 1945.

Did the Romanian socialist regime connect the official discourse of gender equality with the practices? This article focuses on five male activists of the RCP who perpetrated spousal violence in the 1950s. It considers that how the RCP, through CPC, managed these cases of spousal violence is indicative of the regime's readiness to acknowledge spousal violence as a social issue and to take action against it by punishing the perpetrators from its ranks.

In their article regarding the research on violence against women (VAW) and the explanatory frameworks employed by scholars to clarify it, the sociologists Edward W. Morris and Kathleen Ratajczak analyzed two hundred articles published in the journal Violence against Women, which deals with this subject. They found out that patriarchy is the most used "theoretical orientation"12 to discuss men's violence against women (in fifty-nine articles of the two hundred, or 29.5 percent), followed by hegemonic masculinity theory (23 percent), male peer support (12 percent), power and control 
(8.5 percent). The rest of the forty-two articles (21 percent) explains men's violence against women as due to particular manifestations of masculinity: hypermasculinity, hostile masculinity, militarized masculinity, Black masculinity, machismo, and female masculinity. ${ }^{13}$ The patriarchy theory states that the social institutions, social relations, and society as a whole are hierarchically organized according to a pattern that gives men the positions of power, privilege, and leadership and relegates women to subordinated positions. ${ }^{14}$ This hierarchy results in men's dominance and control over women realized often through violence. ${ }^{15}$ From the definition of patriarchy mentioned above, it can be deduced that patriarchal masculinity implies the complete men's authority over women and their legitimate right to restore it, even by violent means, when women contest it.

This article considers spousal violence as a patriarchal practice and a manifestation of patriarchal masculinity and argues that although patriarchy was still dominant within Romanian society in the 1950s, the policy-makers, represented by the functionaries of the RCP and CPC, played an equivocal part in combating it: sometimes they took actions against perpetrators, sometimes did not. Consequently, as the case studies will show, the men's dominance over their wives slowly started to vacillate.

The dynamic between the private and the public spheres during state socialism is central to discussions of domestic violence. Traditionally, spousal violence has been seen as a private matter. ${ }^{16}$ Concerning the Soviet Union, Marianna Muravyeva concluded that the Soviet family did not officially constitute a private space but was seen by authorities as a public institution with important public functions, thus Soviet law had to ensure that the family functioned according to socialist standards. ${ }^{17}$ Massino notes that the Romanian socialist state did not recognize a sharp separation between public and private as well, but people managed to find spaces (both physical and mental) where they could avoid the state's intrusions. ${ }^{18}$

\section{The Committee of Party Control and Its Archive}

This article draws on the files of the Committee of Party Control (CPC $)^{19}$ created during the inquiries it conducted at the request of the Party members sanctioned by local organizations. ${ }^{20}$ From its beginnings, the CPC had a small staff. The institution was led by a president and a vice-president and most of the time, it had about twenty employees, except during short periods when the staff numbered around thirty officials (thirty-one in 1956, twenty-nine in January 1968). Its local branches had a president and between two and four members. In the 1950s, many CPC employees were Party veterans from before World War II. ${ }^{21}$ The first president to tie his career to this institution was Constantin Pârvulescu, ${ }^{22}$ a long-time member of the international Communist movement and a veteran of the Russian Civil War.

Immediately after World War II, CPC had ambiguous roles and unclear rules governed its functioning. It was only in 1960 that the Party Statute endeavored to clarify CPC tasks. Yet, CPC functions were determined by practice rather than by official norms and regulations. In everyday practice, the CPC investigated only cases of top party officials, with the misbehavior of rank-and-file members being addressed by the 
party organizations. The CPC was also an appellate body for the decisions of its local branches.

Over time, the CPC produced collective and individual files on different matters, for instance about the veterans of the Spanish Civil War and French Resistance (at the beginning of 1950s); or on individual members politically unreliable from the Party's point of view, such as the former members of the Romanian fascist movement (the Iron Guard) who had concealed their past when they applied for Party membership or were found guilty by the CPC local branches and/or courts of law of different crimes (theft, bribery, rape, assault).

This article draws on CPC files relating to cases of Party members sanctioned by the CPC local branches for spousal violence who, unhappy with the sanction, contested it at the CPC. The files made by the CPC do not contain initial inquiries conducted at the local level, which are likely to be in local archives. When a Party member did not contest a sanction dictated against him by a local organization of the $\mathrm{RCP}^{23}$ the issue remained at the local level and the documents regarding the sanction were kept in the personal file of the person who was sanctioned. The personal file provides richer information about a person's marriage (when and where the spouses met, the amount of time from acquaintance to marriage, when the marriage took place); about the spouse ${ }^{24}$ (the age and the profession before and after marriage) ${ }^{25}$ and the circumstances surrounding the domestic abuse, though even in personal files domestic violence is addressed only discreetly. At the same time, the cases of spousal violence are much harder to identify in the personal files because of an archival organization issue: the inventories of the funds that contain personal files of the Party members only provide a list of names, without further information on the file's content.

\section{Legislation and the Party Statutes}

Before discussing the relationship between spousal violence, politics, and men in Romania in the 1950s, it is worth examining the legal status of the victims of spousal violence; and also, the terms of the legal structures and regulations that might have been applied to cases of spousal violence. This part will discuss the crimes stipulated by the Romanian Penal Code with which, in theory, the perpetrators of spousal violence could have been charged. If the perpetrator of spousal violence convicted in a court of law was a Party member, the RCP sanctioned him as well, on grounds stipulated by the Party Statute. That is why the next paragraphs will also provide the provisions of the Party Statute applicable, in theory, to violent husbands. The final part of this article will discuss how and when the CPC applied the regulations of the Party Statute to cases of spousal violence and when it did not apply them.

The Civil Code of 1864, whose enactment marked the beginning of the modern Romanian state, did not also bring women into modernity. It maintained limitations on women's property rights and granted them no political or civil rights. In the Principalities, ${ }^{26}$ women had no legal authority to sign contracts, could not control their own dowry, and could not inherit without their husband's consent. Because of their complete economic dependence on men (fathers or husbands), divorce was not an 
option for most women, with very few filing for it. ${ }^{27}$ It took until 1929 for married, high-school educated women to gain the right to vote and run for office in municipal elections. In 1932, married women were granted the right to control their property and sign contracts without their husbands' approval. ${ }^{28}$ It was only after World War II that women received full suffrage, although the vote itself became a mere formality.

The Family Code of $1954^{29}$ addressed issues of marriage, divorce, inheritance, and paternity according to the Soviet model. It abolished the dowry, a fundamental component of women's economic relationship to men, and granted women equal legal status, meaning women could enter into contracts on equal footing with men and control their property and income. The Code established equal decision-making power within marriage, including the initiation of the divorce. By granting women equality with their husbands (in 1954) and the right to choose the termination of pregnancy (in 1957), the Romanian state took important steps toward women's emancipation. ${ }^{30}$ However, a huge gap existed between the law and its implementation. ${ }^{31}$

Spousal violence, which may be considered a violation of the Family Code regarding women's equality with men within marriage, was not explicitly addressed by Romanian criminal legislation. ${ }^{32}$ The communists amended the Penal Code of 1937 in 1948, 1955, 1958, and 1960, ${ }^{33}$ but many of its sections and even articles remained almost identical to the royal Penal Code of 1937. It was the case of the crimes applicable in cases of spousal violence-assault and physical injury, proscribed by Article 470 of the Penal Code of 1937, and 471-481, respectively; and also of other crimes often connected to spousal violence, such as adultery, defined by Article 445, and family abandonment, forbidden by Article $454 .{ }^{34}$

The Penal Code codified the crimes applicable in cases of spousal violence in the title Crimes and Offences against Persons. Assault was punished with one to two months imprisonment, three months when bruising resulted. ${ }^{35}$ Physical injury, which was of three types (simple, severe, and grievous), was punishable by two months ${ }^{36}$ to six years. ${ }^{37}$ The Penal Code of 1955, adopted one year after the Family Code, expanded the penalty for physical injury from five to six years imprisonment. In my understanding, the regime's decision to toughen the penal legislation in the second half of the $1950 \mathrm{~s}^{38}$ was because of a new repressive upsurge, which targeted real and potential political enemies.

Although assault and physical injury were not gendered crimes in Romanian penal legislation, one provision might be considered gendered. Article 473 stipulated that a perpetrator convicted of causing an abortion might spend up to six years in prison. However, abortion was only one of the multiple forms of the crime of physical injury enumerated in Article 473 and punishable with six years in prison. Yet, intra-family violence was a matter of concern for the Romanian criminal law, but only if it occurred between blood relatives or the victim was younger than fifteen years old, cases when a convicted perpetrator might face up to eight years imprisonment. ${ }^{39}$ The criminal proceeding for assault and physical injury ${ }^{40}$ started only if the victim had filed a formal complaint. ${ }^{41}$ If the reconciliation between victim and perpetrator had occurred, the criminal trial ceased.

In all five case studies discussed in the next part of this article, spousal violence was accompanied by adultery and family abandonment. Criminalized by the Roma- 
nian Penal Code in the section Crimes against the Family, both of them were considered non-violent misdemeanors. Adultery was defined as "sexual relations outside marriage," regardless of the perpetrator's gender, and might be punished by one to six months imprisonment. Yet, adultery was an offense difficult to prove in court. It could be proved only if the perpetrators were caught in the act or with letters written to each other. $^{42}$

Sometimes, the violent, adulterous men went further and deprived their legitimate wives and children of economic resources, care, and parental support. In Article 454 about family abandonment, the Romanian Penal Code criminalized one person's failure to provide as breadwinner and penalized it with three months to one year in prison. According to Romanian law, three situations were considered family abandonment: when a person departed from home and refused the material and moral support to those whom that person had the legal obligation to provide for; or even when the person, out of avarice, for instance, refused to provide for his wife and children and exposing them to physical and moral decay; or when a person refused for three months in a row to pay the obligations laid down by a court order. ${ }^{43}$

Family abandonment was not a gendered crime in the Romanian criminal legislation either. Throughout it, Article 454 used the noun "spouse" in the masculine but implied both spouses. In practice, men were put on trial for family abandonment, ${ }^{44}$ probably because in a patriarchal society, as it was in Romania in the 1950s, very rarely were married women the single provider for the family. Albeit there are no statistics regarding the head of the households' gender, the gender structure of the labor force might support this conclusion. In the 1950s, women's employment outside the home fluctuated wildly, from a peak of 45.3 percent in 1958 to a low of 26.7 percent one year later, in $1959 .{ }^{45}$ To a broader extent, the breadwinning likely remained a constituent part of "typical" masculinity.

The state and the Party were governed by separate rules. Party members were obliged to respect the Statute-the supreme law that regulated the functioning of the Communist Party. If Party members violated the rules established and enforced by the RCP institutions, to which they agreed voluntarily to submit (as opposed to the Constitution and other laws of the state, which one had to uphold by virtue of being a citizen of that country), they could also be penalized with punishments that could extend as far as exclusion.

Article 3, paragraph (c) of the 1945 Statute stipulated that each member was obliged "to be an example of moral conduct," 46 but did not define moral conduct. The Statute of 1948, Article 7, paragraph (d) required members "to be a model of honesty and moral conduct in public and personal life" (emphasis added). ${ }^{47}$ The Party's most important document distinguished between the public and private existence of an individual but still did not specify what its authors meant by moral conduct. The Statutes of 1955 and 1960 addressed the problem of conduct indirectly: morality was not listed among the obligations that Party members had to observe, nor was it among the prerequisites for becoming a Party member. ${ }^{48}$ A reference to morality appears in Article 13, which enumerated the grounds for expulsion: "Expulsion is applicable ... in cases of moral dissolution (descompunere morală) or when a member perpetrates acts incompatible with Party membership. ${ }^{\prime 49}$ It did not define either moral dissolution or acts in- 
compatible with Party membership. Crimes so vaguely defined in the most important document of the RCP empowered the Party functionaries to assess different life situations according to their own understanding. Yet, the Statute of the Communist Youth Organization of 1958 was clearer regarding moral obligations. Article 2, paragraph (g) stipulated that a member of the Organization had to be "honest, upright, modest and courageous, to follow the rules of the communist morality, to fight alcohol abuse, hooliganism, and un-comradely (netovărășești) attitudes toward women." ${ }^{\prime 50}$

\section{The Rotten Apples from the Party's Orchard}

To examine how the RCP dealt with cases of Party members charged with crimes and offenses against spouses and families, I have selected five cases from the CPC archive out of 210. In 1950s state-socialist Romania, rarely did spousal violence manifest itself as an isolated issue. It was often accompanied by adultery and alcohol abuse. That is why I chose five cases in which spousal violence intersects with adultery and family abandonment. ${ }^{51}$

The mass mobilization of women for paid employment after World War II increased men's opportunities to meet girlfriends. The workplace became not only a site of male sociability but a place for male-female sociability. M. M., I. B., and St. B., three of the five abusive men whose cases this part discusses, met their mistresses at work, in their social circle. Circumstances eased M. M.'s path to adultery: conveniently, his girlfriend worked with him at Ploiești City Hall. Caught between his job, the new love, and a group of friends, M. M. was rarely home, the Party official assigned to his case noted. ${ }^{52}$ The young engineer physically abused his wife because she discovered his adultery and reproached him for it..$^{33}$

I. B., a skilled worker who had completed seven grades, joined the RCP in 1948 and soon after was appointed head of the Propaganda Department of the Corabia District Committee of the RCP. In the 1950s, he was in his thirties, married with two children, and had an extramarital affair with a female subordinate.$^{54}$ The CPC male official in charge of investigating his case ${ }^{55}$ made a causal link between adultery and domestic violence: "I. B. . . . had intimate relations with V. S., an activist in the section he ran, for which reason he battered his wife." ${ }^{156}$ The CPC official did not give additional details, for instance why exactly I. B. battered his wife, nor other circumstances that would allow us to speculate about the cycle of abuse.

A janitor in his youth, St. B. joined the RCP in 1946 and in 1949 was appointed head of the Administrative Department of Olt County Committee of the RCP. Married and the father of one child, this activist also had a love affair with a female subordinate who worked at the Party canteen. At the same time, he was beating his wife. His CPC file just mentioned the spousal violence as a fact, with no further details about reasons, frequency, circumstances. St. B. divorced, and after that, he had sex at the workplace with an eighteen-year-old female caretaker; she was half his age. ${ }^{57}$

In each of these cases, the mistresses had employment outside the home but in positions subordinate to their lovers. The CPC files mentioned the wives only as victims of spousal violence. No information about their age, education, or career is provided, 
or about the duration of the marriage. For this reason, it is impossible to assess if a competition occurred for men's attention between housewives and the girls employed outside the home, or if traditional assumptions about women's subordination to men were manifest in adultery and spousal violence and, more generally, in men's dominance over their wives. ${ }^{58}$ The CPC files do not provide the mistresses' marital status either. This information could have been useful for evaluating men's reaction to female adultery in Romania in the 1950s. We know only that M. M.'s girlfriend was married to a Romanian army officer with whom she had a child. The officer knew about his wife's love affair but ignored it. ${ }^{59}$

Why did the adulterous men M. M., I. B., and St. B. abuse their legal wives? In her research on marriages in Walachia in the eighteenth century, Constanța VintilăGhitulescu identified cases of adulterous men who beat their wives to death because they believed the wives stood between them and the happiness that only new lovers could bring. ${ }^{60}$ We can speculate that this might have been the case with M. M. and I. B. Although two centuries separate the cases analyzed by Vintilă-Ghitulescu from those discussed in this article and much had changed since then in women's legal status, patriarchal beliefs about gender and marriage proved hard to tackle, for example, man's domination over his wife, manifest in adultery and spousal violence. Jill Massino noticed that during socialism, marital relations continued to be influenced by traditional notions of gender. ${ }^{61}$ The patriarchal norms about gender allowed men to believe that they may behave how they want, with no need to explain to wives their choices and behaviors.

Does the extramarital relationship between male bosses and female subordinates indicate gendered abuse of power? Is sexual harassment manifest in it? ${ }^{62} \mathrm{I}$. B. and his mistress appear to have had a consensual relationship. They wrote letters to each other, just like any other lovers. This activist from Corabia town likely had an extramarital relationship only with this woman, in any case, the CPC file recorded only this love affair. Things seem to have been more complicated with St. B., who had a serious extramarital relationship with the cook from the Party canteen. As in the cases of M. M. and I. B., both parties likely agreed. When he went out of town for work, St. B. often took his mistress with him. "He used the accommodation provided by the Party with this woman,"63 wrote the CPC official assigned to St. B.'s case, perhaps wanting to point out that the activist was abusing Party resources with persons who were not entitled to benefit from them, in this case with his mistress, who was also a Party employee, but in a minor position. The CPC file does not say whether St. B. continued the relationship with his lover after his divorce. Instead, the report compiled for St. B.'s case mentions that after the divorce, the 44-year-old official had sexual relations with a female subordinate who was twenty-six years younger, "abusing the position of Head of the Administrative Section." 64 The CPC clerk suggests that St. B. had made use of his senior position in the RCP hierarchy to force his subordinate to have sex with him.

The Party distinguished between men who abused their wives because of a single extramarital relationship, such as M. M. and I. B., and men who behaved violently in general, both inside and outside the home. This seems to have been the case of V. B., a Securitate ${ }^{65}$ Lieutenant. V. B. was born to a peasant family. When he was eighteen years old, he joined the RCP and four years later, he was hired in law enforcement. After 
he graduated from a one-year school for Securitate officers, he was promoted to lieutenant. V. B. was married and the father of one child when he started abusing his wife. His CPC file mentioned that he was also a hard drinker and a womanizer but did not say from which facts the Party official who authored the report drew this conclusion. ${ }^{66}$

In the cases investigated for this article, the focus of Party actions were the abusive men, not the victims of their abuse. Yet, women were not just passive victims of spousal violence. Isabel Marcus has noticed that during socialism, women in Poland, Hungary, and Romania exercised agency in their relationships, resisting spousal abuse ${ }^{67}$ Four of the five women whose marriages this article discusses confronted domestic violence obliquely, by taking a stance against adultery, family abandonment, or their husbands' intention to seek a divorce, probably because the Romanian Penal Code criminalized adultery and family abandonment, but not spousal violence. ${ }^{68}$ However, victims of spousal violence had the legal option to press charges against their aggressor for assault or physical injury, codified in Romanian criminal legislation as a non-gendered misdemeanor. These four victims of spousal violence tried to resist abuse, but their ultimate goal seems to have been to preserve the marriage at any cost, even one with an abusive man. In traditional societies, marriage was often a response to economic needs. In Romania, during the 1950s, socialism and tradition coexisted, women still being vulnerable to poverty in case of divorce. We can speculate that the wives of M. M., I. B., V. B., and M. B. (whose case we shall discuss below) were more concerned with the economic aspect of their marriages. Additionally, they likely avoided divorce being afraid of the "social stigma and personal vulnerability associated with it." 69 Jill Massino noted that even in the 1980s, women feared the social stigma that accompanied divorce. Massino also noted that, during state socialism, women chose to suffer in silence because of social pressure: to suffer quietly was what society and even family expected them to do.

After six years of marriage and one year of an extramarital affair, in the autumn of 1959, M. M. filed for divorce at Ploiești Tribunal. In the divorce petition, he wrote that he had not initiated the procedure earlier, fearing the reaction of public opinionfriends, acquaintances, colleagues, friends. ${ }^{70}$ Although she was a victim of spousal violence, it was not St. B's wife who ended the marriage but him. ${ }^{71} \mathrm{~V}$. B's matrimony also ended on the initiative of the abusive man. First, the Securitate Lieutenant left his home, his sick wife, and their child and went to "live with various women."72 $\mathrm{Ill}$ and unable to provide for her and her child's livelihood, the wife sued him for family abandonment. The CPC file does not provide the chronology of the two trials, for divorce and family abandonment. It noted only that the Securitate Officer lost the trial for family abandonment, Dej Town Tribunal ruling in his wife's favor. By Sentence No. 3078 of 9 December 1955, it ordered V. B. to pay his family alimony of 200 lei per month. V. B. refused to fulfill this obligation for several months in a row. Defended by court order, the ex-wife sued him again, ${ }^{73}$ because the Romanian legislation defined refusal to pay alimony as a form of family abandonment.

In the early 1950s, in circumstances not detailed in his CPC file, M. B. also faced charges of "family abandonment and repeated wife-beating." ${ }^{\text {"74 }}$ The file does not mention what crime he was charged with. M. B. was a shoemaker from Ineu, Arad county, with a fourth-grade education, who owned his workshop. This man had also been a 
member of the city council, elected in 1937 to the list of the National Peasant Party. He was married, but the CPC file does not mention if he had children. The shoemaker was in his fifties when the Communists took power. He switched sides quickly and joined the RCP in 1945. After the state took over his business, he took up administrative responsibilities at the Apollo cinema in Ineu. Regarding the trial for family abandonment and spousal abuse, the CPC file does not detail who made the complaint, when, and on what grounds-domestic violence, family abandonment, or both. But because the Penal Code stipulated that only the victim could press charges against her aggressor, it turns out that his wife did, since he was on trial for "family abandonment and repeated wife-beating." 75 The CPC file only records the end of the story: M. B. was not convicted. Yet, it does not mention whether the Tribunal acquitted him or the wife withdrew her complaint, which automatically ceased the penal trial. ${ }^{76}$

Two women dealt with adultery in other ways than suing their husbands: the wives of M. M. and I. B. confronted "the other woman" publicly. We can speculate that they likely blamed the mistresses for their husbands' infidelity and aggressive behavior. On the evening of 21 October 1959, upon learning that M. M. was with his mistress at a friend's house, his wife went there too. The information proved correct, the two lovers being right there. I. B.'s wife used the same strategy. She stormed to the house of her husband's girlfriend and smashed all the windows. I. B. was inside but could do nothing to stop the scene. ${ }^{77}$

In none of the cases analyzed in this article did the RCP, as an institution, sanction its male members for domestic violence. The Party dealt with domestic violence only obliquely and replied to marital issues in three situations: when the couple's problems became the subject of gossip, rumors, and public scandal; in the case of a divorce with minor children; or after criminal convictions for other family crimes.

Sometimes women aired family problems, as in the cases of M. M. and I. B. Other times, the adulterous and abusive man used public spaces to have sex, such as St. B., who had sex with a young female subordinate in a Party building, and it is very likely that they were caught, as long as the situation turned public. In this way, adultery became notorious and, with it, the couple's other problems, such as domestic violence, came to the surface. Once a marital issue became a matter of public discussion, the Party was forced to recognize it as a problem, to deal with it, and even to take sides. The RCP became preoccupied because the reputation and credibility of its officials in the eyes of the public were at stake. The CPC male clerk assigned to I. B.'s case wrote that the scandal caused by his wife at his mistress' home created "a bad atmosphere in the town." ${ }^{78}$ In small municipalities, people knew each other personally, so RCP officials were right to fear that a juicy story about a Party activist, his wife, and his mistress would spread quickly. The inhabitants of Dej, also a small town, although larger than Corabia, ${ }^{79}$ knew about Lt. V. B.'s abusive behavior toward his wife-the CPC file does not mention how the social group learned about it. In any case, the wife-beating "compromised V. B. in front of the citizens and soldiers he commanded," CPC official assigned to his case.

Usually, the Party tried to stop domestic conflicts at their beginnings as discreetly as possible through informal and formal discussions with the perpetrators, if the perpetrators were Party members. Only if this approach failed were tougher measures 
used, such as discussing the case in a meeting of the primary Party organization (organizatie de bază $)^{81}$ from the perpetrator's workplace and applying one of the sanctions stipulated by the Party Statute. Luciana Jinga briefly discussed the strategies employed after 1966, by the Party, mass organizations, and legal experts to persuade women to renounce divorce ${ }^{82}$ or complains of spousal violence. ${ }^{83}$ In 1966 , restrictive legislation regarding divorce and abortion was adopted. Jinga noted that it was a practice to involve the "committee of reconciliation" in cases of divorce, rape, seduction, and spousal violence, committees that worked as "moral tribunals." However, it is unclear if the practice existed before 1966 as well. Further research might clarify what proportion from the total number of perpetrators of spousal violence appeared in front of the primary Party organizations and how effective the Party sanctions were.

In 1959, in the love triangle between M. M., his wife, and his mistress, the Party sided with the jilted wife and exerted repeated pressure on M. M. to end the extramarital relationship. Officials from the Cadre Section from Ploiești City Hall, the President and the Secretary of the Party Organization of the same institution, an instructor of the Ploieşti Committee of the RCP-each summoned the perpetrator and talked to him. The primary Party Organization of Ploiești City Hall discussed the case in two meetings. On 10 October 1959, after M. M. filed for divorce, the Bureau of the RCP primary Organization of Ploiești City Hall summoned M. M. again and made him promise to end the extramarital relationship and withdraw the divorce lawsuit. Under the pressure exerted by the social group, M. M. agreed to withdraw the divorce lawsuit and end his extramarital affair but he did not finish it right away. The wife found out, which led to the episode on the evening of 21 October, described above, and opened the door for other consequences.

The scandal perpetrated by M. M.'s wife at the mistress's house triggered the Party reaction. The primary Party Organization of the RCP of Ploiești Town Hall produced a report on short notice and five days after the scandal, an extraordinary meeting of the general assembly of this primary Party Organization was held. In the case of I. B., it is worth noting that his situation was discussed at a high level of the Party hierarchy, at the Craiova Regional Committee of the RCP. ${ }^{84}$

The meetings of the general assembly of a Primary Organization of the RCP had to observe strict protocols. ${ }^{85}$ A rank-and-file member read the report concerning the case, which highlighted the difference of social status between young engineer M. M. and his worker wife as a ground for adultery and the unfairness of such an attitude: "it turns out that, at this very moment, when he secured a better career, his wife, very compatible in the past, is unsuitable today and our comrade can't stand her anymore." 86 M. M. defended his case and after that, twenty-four rank-and-file members questioned him. Of the twenty-four members who asked questions, five were women. Some questions concerned adultery. M. M. was asked if his love affair with a female co-worker distracted him from his duties, which suggests that the Party discouraged romantic affairs in the workplace because of their disruptive potential. Two male Party members asked M. M. if he had brutalized his wife. He asserted that he "neither hit her nor beat her during this period, there was a small incident but long before." 87 It is apparent from his answer that M. M. distinguished between "hit" and "beating." By "hit" he meant a 
single, non-recurring incident. The attempt to place the spousal abuse in a distant past and to sell it as a unique, isolated incident (it only happened once) and unimportant (small) suggests that M. M. tried to downplay any spousal violence. He also tried to diminish his blame by saying that he "brought all the money home," 88 that he was not evading his role as a breadwinner. His comrades, men and women alike, accepted these explanations. The comrade who had asked the question about spousal violence did not insist on finding out what M. M. meant by a "small incident." Another woman shifted the questioning to focus on adultery, wanting to know how long the extramarital relationship had lasting and whether M. M.'s girlfriend had asked him to file for divorce. Female Party members either asked vague, political questions or expressed interest in adultery, but did not touch on the issue of domestic violence at all. In our understanding, the explanation for this situation is twofold. In state socialist regimes, the political identity prevailed, and that is why women strived to prove that they were first of all "good communists," not less than male-Party members. To prove their communist faith, these women from Ploiești City Hall endeavored to transcend their gender, traditionally associated with sensibility and irrationality, to ask "serious," "male" questions, and to demonstrate that they assess the situation objectively, not through the lenses of gender solidarity. Second, women seemed less concerned with spousal violence because it was commonplace. ${ }^{89}$ The female Party members also asked about the couple's child who had been adopted by a relative. Men were interested as well in M. M.'s paternal side. A comrade asked M. M. how he felt when his child calls another man "father." The engineer asserted the child had been adopted when he was three weeks old, not long enough for the biological father to develop paternal feelings. All questions, however, had a political connotation, highlighting the mismatch between M. M.'s behavior and his Party membership. This ritual finger-pointing at M. M. defined him as an inadequate Party member, not as an abusive husband.

The extraordinary general assembly voted unanimously to reprimand M. M. for his "unfair attitude" (attitude nejustă) toward his family and "inadequate habits" (apucături necorespunzătoare). ${ }^{90}$ The Party organization took into consideration M. M.'s age, social origin, and education as mitigating circumstances. "He is young. Let's not throw him into the enemies' hands. He still has time to learn good behaviors,"91 asserted a male Party member. Another one underlined M. M.'s "good social origins," saying his parents had been workers. A third participant bluntly asserted that the family issues were, undoubtedly, unpleasant, but not a serious enough reason for excluding a man from the Party.

The Olt County Committee of the RCP sanctioned St. B. also with a reprimand, for divorce. The CPC official in charge of this case wrote that the activist divorced "even though he had a child." 92 The concession sentence used by the Party official expresses a circumstance (St. B. had a child) that should have prevented the action in the main sentence (St. B. divorced), but which did not prevent it. The very existence of a child should have discouraged St. B. to file for divorce, but it did not discourage him. This is how the CPC official assessed St. B.'s decision to file for divorce, from which it can be deduced that the RCP did not penalize men who divorced spouses, but fathers who abandoned minor children. After 1965, the RCP tried to prevent divorce and family abandonment because of the regime's reproductive policies but also because the com- 
munists blamed divorce for juvenile delinquency. ${ }^{93}$ It seems that this belief existed even before 1966, the year considered a watershed in the Romanian's regime family policies.

I. B., the adulterous man whose wife had broken the windows of his mistress' house, was prohibited from holding senior positions in the Party and State hierarchies for a year, for "immoral misconduct" (abateri imorale), ${ }^{94}$ by which the RCP officials meant adultery; and for the attempt to mislead a Party investigation. Initially, I. B. denied the extramarital relationship and admitted to it only when investigators produced material proof-his mistress' letter to him. Although mild, the sanction cost I. B. his political career: because he held a senior position in the Corabia Committee of the RCP, he lost it and had to find employment as a skilled worker at Electroputere, a large plant in Craiova. However, he was not purged from the Party.

The RCP used exclusion as a last resort when all other measures failed to accomplish their educational goals. ${ }^{95}$ In theory, the Statute of the RCP in force during the 1950s did not prohibit persons sentenced to prison to continue being Party members, but, in practice, the RCP purged persons sentenced to prison. That was the case with M. B. and V. B., who had been prosecuted twice each. Both V. B.'s trials were for family offenses; M. B.'s-one for family offenses, the second for abuse of power, a crime committed in his professional capacity. M. B. was not convicted in the trial for family abandonment and spousal violence but in November 1951, he was sentenced to a sixmonth suspended prison term for abuse of power. In his first trial of 1955, V. B. was sentenced to pay alimony. This sentence had no political consequences. The Party did not punish V. B. for the domestic violence, adultery, and family abandonment but his employer did: in 1956, the Securitate fired the Lieutenant "because of his serious misbehaviors." 96 V. B. was relegated to working in a mine as an unskilled worker. In 1957, by Sentence no. 744 of 8 May, the Dej Tribunal convicted V. B. to six months imprisonment for refusal to pay alimony. After the criminal convictions, M. B. and V. B. were excluded from the Party.

\section{Conclusions}

This article dealt with spousal violence in Romania in the first decade of the state socialist regime by analyzing five cases of minor activists of the RCP who perpetrated spousal violence accompanied by adultery and family abandonment. In the 1950s, the state socialist regime in Romania took legal steps toward women's emancipation. The Family Code of 1954 abolished the dowry, a fundamental component of women's economic relationship to men, and freed the women who, then onward, could enter into contracts on equal footing with men and control their property and income. The Code abolished marital authority, establishing equal decision-making power within marriage. However, the criminal legislation of the time did not support the generous principles of the Family Code. The Penal Code did not criminalize spousal violence explicitly, and it defined the crimes applicable to it as misdemeanors. The inconsistencies of legislation left the door open to marital abuse and to men's domination. A 
disconnection existed between the official discourse and the daily practice regarding gender equality. Although protected by the law and the official discourse, women continued to fall victim to spousal violence.

Although not the only driving force capable of imposing structural changes, the RCP was seen as a significant player within state socialist regimes. Thus, the way the Party managed the discussed cases of spousal violence gives an idea about how gender relations functioned in reality, beyond the official discourse and the letter of the law. It also indicates the Party's readiness to challenge the patriarchal order.

Despite a few notable exceptions, the political elite that emerged after World War II continued to be a men's club. The CPC officials were mostly men and that is why the cases of spousal violence were assessed from a masculine perspective. The RCP's male officials did not sanction the male activists solely for domestic violence. Although the official discourse privileged political identities, it is likely that a sort of male solidarity existed.

The Party reacted in three situations: when the marital problems of the activists, including spousal violence, became the subject of gossip, rumors, and public scandal; if the abusive activist filed for divorce and had children; or if the violent activist had been convicted for family crimes (adultery or family abandonment). Once a marital issue became a matter of public debate, the Party was forced to recognize it as a problem, deal with it, and even take sides. Even when spousal violence existed in the picture, the Party pushed hard to preserve the activists' marriages, especially those with children. Spousal violence accompanied by a conviction for adultery or family abandonment became matters of concern for the Party because the reputation and credibility of its officials were at stake. A preoccupation for appearances is what all these three situations had in common. The image of a caring husband and father was the ideal type of male activist traded by communists to society, to serve as a role model. The Party usually dictated sanctions against abusive male activists when the real men publicly contradicted the ideal type of politician presented by the official discourse.

During state socialist regimes, spousal violence was a political issue, not a gender issue. When the Party sanctioned its male activists for spousal violence, it did it because it considered spousal violence a political mistake, not an abusive behavior that had to cease in the "brave new world" that the regime promised to inaugurate.

\section{$\diamond$ About the Author}

Cristina Diac is a senior researcher within the Romanian Academy's National Institute for the Study of Totalitarianism. She also teaches courses on the communist movement between the two world wars and contemporary Romanian history (1965-1989) at the University of Bucharest's Faculty of History. She has conducted research in archives in Romania, the Russian Federation, Bulgaria, Hungary, Slovakia, and France, and published extensively on communist elites, networks of transnational anti-fascism, the Communist Party as an institution, and political activism in twentieth-century Romania. 


\section{$\diamond$ Notes}

1. M.M.'s autobiography of 21 April 1959, The National Archives of Romania (hereafter ANIC, after the Romanian abbreviation), fund Central Committee (hereafter CC) of the RCPCadre Department, file M/1684, 29/v.

2. Report concerning M. M.'s case of 24 October 1959, ANIC, fund CC of the RCP-Cadre Department, file M/1684, 40 .

3. Michele Harway and James M. O’Neil, “What Causes Men to Be Violent against Women? The Unanswered and Controversial Question," What Causes Men's Violence against Women? Foreword by US Senator Joseph R. Biden, Jr., ed. Michele Harway and James O'Neil (Thousand Oaks: Sage Publications, Inc., 1999), 8.

4. Because the state socialist regime in Romania criminalized same-sex acts, this article deals with heterosexual marriages.

5. Michael Flood, "Domestic Violence," Men and Masculinities: A Social, Cultural, and Historical Encyclopedia, Volume I: A-J, ed. Michael Kimmel and Amy Aronson (Santa Barbara, CA: ABC Clio, 2004), 234-239.

6. Lisa Semenoff, "The Women's Movement and the Responses to Violence against Women in the USSR and Post-Soviet Russia" (MA thesis, Ottawa: Carleton University, 1997).

7. Sharon Horne, "Domestic Violence in Russia," American Psychologist 54, no. 1 (1999), 57.

8. Jill Massino, Ambiguous Transition: Gender, the State and Everyday Life in Socialist and Postsocialist Romania (New York: Berghahn Books, 2019), $243 \mathrm{n} 77$.

9. Maria Bucur and Mihaela Miroiu, Birth of Democratic Citizenship: Women and Power in Modern Romania (Bloomington: Indiana University Press, 2018), 51-53.

10. Massino, Ambiguous Transition, 19.

11. Luciana M. Jinga, "Comrade First, Baba Second: State Violence against Women in Communist Romania," History of Communism in Europe, vol. 8 (2017), The Other Half of Communism: Women's Outlook, ed. Luciana M. Jinga (Bucharest: Zeta Books, 2018), 63-86, here 72, https:// doi.org/10.5840/hce201784.

12. These authors make a distinction between "theories," among which they enumerate the social constructionism, social learning, doing gender, and performativity, and a "theoretical orientation." They define patriarchy as both a theoretical orientation and a theory, and even as a general concept. Edward W. Morris and Kathleen Ratajczak, "Critical Masculinity Studies and Research on Violence against Women: An Assessment of Past Scholarship and Future Directions," Violence against Women 25 (2019), 1982-1983. https://doi.org/10.1177/1077801219875827.

13. Ibid.

14. R. Emerson Dobash and Russell Dobash, Violence against Wives: A Case against the Patriarchy (New York: Free Press, 1979), 43.

15. Morris and Ratajczak, "Critical Masculinity Studies," 1983.

16. Katalin Fábián, ed., Domestic Violence in Postcommunist States: Local Activism, National Policies, and Global Forces (Bloomington: Indiana University Press, 2010), 1.

17. Marianna Muravyeva, "Bytovukha: Family Violence in Soviet Russia," Aspasia 8, no. 1 (2014), 90-124, here 94, https://doi.org/10.3167/asp.2014.080106.

18. Massino, Ambiguous Transition, 28n22.

19. The Committee of Party Control (CPC) of the Central Committee (CC) of the RCP was established at the National Conference of October 1945 and existed until December 1989. Details on the functioning of the institution extracted from its internal documents are available at Mircea Stănescu, "Comisia de Control a PCR (1945-1989): Prezentare de fond și istoric" [The Committee of Party Control of the Romanian Communist Party (1945-1989): A presentation of the institution and of its archival fund], Archiva Moldaviae [Archive of Moldavia] no. 3 (2011), 
275-316. Details concerning the first two years of existence of the CPC at Stefan Bosomitu, "Instituționalizarea aparatului de control al Partidului Comunist: Comisia de Control a C.C. al P.C.R., 1945-1947" [The institutionalization of the control within the Romanian Communist Party: The Committee of Party Control of the Central Committee of the Romanian Communist Party, 1945-1947], Arhivele Totalitarismului [Totalitarianism Archives] 24, no. 3-4 (2016), 57-81.

20. Edward Cohn uses this type of source in his research about the Soviet Union. Edward Cohn, "Disciplining the Party: The Expulsion and Censure of Communists in the Post-War Soviet Union, 1945-1961" (Ph.D. dissertation, Chicago: University of Chicago, 2007).

21. Until the mid-1970s, most vice-presidents were also prewar Party members. Ion Vințe was a vice-president of the CPC between 28 December 1955 and 12 August 1969; Lyuba Chişinevschi-between 28 December 1955 and 25 June 1960; Simion Bughici-between 12 August 1969 and 28 November 1974. Membrii C.C. al P.C.R. 1945-1989. Dicționar [Members of the CC of the RCP. Dictionary], Studiu introductiv: Nicoleta Ionescu-Gură, coord. Florica Dobre (Bucharest: Editura Enciclopedică, 2004), 618, 150, 116-117.

22. C. Pârvulescu ran the CPC authoritatively from 1945 to 1960 and was succeeded by another veteran, Dumitru Coliu, who ran the CPC for nine years.

23. M. M. is such a case.

24. The CPC files rarely give details about the victim of domestic violence (e.g., whether she was working outside the household or was a housewife) and about marriage.

25. In the case of the high nomenclature, many spouses, although educated, gave up their careers after marriage.

26. The Principalities of Wallachia and Moldavia were two medieval states founded in the fourteenth century that remained independent under Ottoman suzerainty. In 1859, Wallachia and Moldavia formed a personal union under the reign of A. I. Cuza. The new state was autonomous but remained under Ottoman suzerainty until 1878.

27. In her research on the eighteenth century, Constanța Vintilă Ghițulescu noticed that spousal abuse and adultery were the most frequent grounds invoked by women for seeking a divorce. In the sample which comprises 420 divorce cases, 269 petitions were lodged by women and 151 by men. Almost all of the 269 petitions refer to marital violence. Constanța Vintilă Ghițulescu, "Judicial Archives and the History of the Romanian Family: Domestic Conflict and the Orthodox Church in the Eighteenth Century," The History of the Family 18, no. 3 (2013), 261277, here 265, https://doi.org/10.1080/1081602X.2013.781950; Constanța Vintilă Ghițulescu, In șalvari și cu ișlic. Biserică, sexualitate, căsătorie și divorț în Țara Românească a secolului al XVIIIlea [Shalwars and fur top hats: Church, sexuality, marriage, and divorce in eighteenth-century Wallachia], Ediția a II-a revăzută și adăugită [Second, revised and expanded edition] (Bucharest: Humanitas, 2011), 14. However, as the cited author herself remarked, the impact of divorce within the Romanian society of the eighteenth century was rather low. Bucur and Miroiu drew the same conclusion regarding the impact of divorce in the eighteenth century. Bucur and Miroiu, Birth of Democratic Citizenship, 20.

28. Bucur and Miroiu, Birth of Democratic Citizenship, 22, 27.

29. Published in Buletinul Oficial [The official bulletin], no. 9, 31 January 1954.

30. Massino, Ambiguous Transition, 198.

31. Bucur and Miroiu, Birth of Democratic Citizenship, 30.

32. L. Jinga makes the same point. "Comrade First, Baba Second," 75.

33. Because the articles applicable to cases of spousal violence, namely those that criminalized assault and physical injury, are identical in 1948, 1955, 1958, and 1960, with one exception that will be marked, this article will quote the Penal Code of 1948.

34. Codul General al României (Codurile, Legile și regulamentele în vigoare) 1856-1937 [Romanian legislation (The codes, laws, and regulations in force) 1856-1937], vol. XXIV: Coduri, legi 
și regulamente cuprinzând prima parte din legislația anului 1936 [Codes, laws, and regulations adopted in the first half of 1936], Partea I (Bucharest: Monitorul Oficial și Imprimeriile Statului. Imprimeria centrală, 1937), 90-91, 86, 87-88.

35. Art. 470, Victor Papadopol, Ilie Stoenescu, G. V. Protopopescu, Codul Penal al Republicii Populare Române adnotat [The criminal code of the Popular Republic of Romania, with comments] (Bucharest: Editura de Stat, 1948), 504.

36. For simple physical injury, when the victim needed no recovery days. Art. 471, Codul Penal al Republicii Populare 1948, 506.

37. The maximum imprisonment for grievous physical injury. Grievous physical injury was that injury after which the victim needed "more than two months recovery" or the victim suffered a permanent physical or mental disability (the loss of a sense, organ, the function of an organ, including the capacity of procreation). Article 473, Codul Penal: Text oficial cu modificările până la data de 20 mai 1955, urmat de o anexă de legi penale speciale [The criminal code: The official version containing all revisions up to 20 May 1955, with an appendix of special criminal laws] (Bucharest: Editura de Stat pentru Literatură Economică și Juridică, 1955), 176-177.

38. In 1958, some articles of the Penal Code were toughened to curb the peasants' resistance to the process of socialization of the land estates. Octavian Roske, "Accente în strategia colectivizării. Articolul $208 \mathrm{Cod}$ Penal" [Accents on the collectivization strategy: Article 208 of the Penal Code of 1958], Arhivele Totalitarismului, 2, no. 1-2 (1994), 277-312.

39. Article 476, Codul Penal: Text oficial 1955, 177.

40. Except for the grievous physical injury.

41. Article 481, Codul Penal al Republicii Populare Române adnotat 1948, 517-518.

42. Article 445, Ibid., 470.

43. Article 454, Ibid., 476.

44. Four out of six examples of sentences handed down by the Romanian courts of law between 1944 and 1947 for family abandonment and presented in the edition of the Penal Code of 1948 quoted in this article are about male perpetrators. Two of six do not refer to specific cases but give general interpretations. Article 454, Codul Penal al Republicii Populare Române adnotat $1948,477-479$.

45. Luciana M. Jinga, Gen și reprezentare în România comunistă: Femeile în cadrul Partidului Comunist Român, 1944-1989 [Gender and politics in communist Romania: Women within the Romanian Communist Party, 1944-1989] (Iași: Polirom, 2015), 232.

46. The chapter "Despre membrii de partid: Îndatoriri" [About Party members: Obligations], Statutul Partidului Comunist Român [The Statute of the Romanian Communist Party] (Bucharest: Editura Partidului Comunist Român, 1945), 13-15.

47. Statutul Partidului Muncitoresc Român [The statute of the Romanian Workers Party], $1948,10$.

48. The obligations were listed in the chapter "Party members: obligations and rights," Article 2: (a)-(l) and concerning politics and profession (e.g., to serve the socialism and the country, Art. 2, paragraph (a); to improve continuously the professional skills and theoretical knowledge of Marxism-Leninism, Art. 2, paragraph (d) and (f)). The prerequisites were enumerated in Article 4 and concerned the profession, readiness to serve socialism, and age. "Statutul Partidului Muncitoresc Român" [The statute of the Romanian Workers Party], Scînteia [The Spark], Friday, 30 Dec. 1955, 3; Article 13 of the final version of the Statute of the RCP to be adopted by the Third Congress. ANIC, fund CC of the RCP-Chancellery Directorate, file 37/1960, 13.

49. ANIC, fund CC of the RCP-Chancellery Directorate, file 37/1960, 13.

50. Statutul Uniunii Tineretului Muncitor din Republica Populară Română [Statute of the Romanian Communist Youth Organization] (1958), 15. 
51. Donna Harsch wrote that in the GDR, drinking, and violence often occurred in tandem and they observed neither class nor political boundaries. Donna Harsch, Revenge of the Domestic (Princeton, NJ: Princeton University Press, 2007), 217.

52. Report of Ploiesti City Hall Organization of the RCP regarding the case of M. M. of 24 October 1959, ANIC, fund CC of the RCP—Cadre Department, file M/1684, 40.

53. Ibid.

54. Report regarding the case of V. B. of 17 January 1959, ANIC, fund CC of the RCP-CPC, file $\mathrm{B} / 2577,3$.

55. In 1956, the CPC had forty employees, of which thirteen were women, three in a high position (one was an inspector, and two were instructors). The rest did auxiliary work (typists). ANIC, fund CC of the RCP-CPC Internal Documents, file 12/1956, 7-10.

56. The decision of CPC of 14 December 1956 regarding I. B.'s appeal, ANIC, fund CC of the RCP-CPC, file B/1290, 3 .

57. Ibid., file B 3567, 1.

58. Massino, Ambiguous Transition, 229.

59. Autobiography of M. M of 21 April 1959, ANIC, fund CC of the RCP-Cadre Department, file $\mathrm{M} / 1684,29 / \mathrm{v}$.

60. Constanța Vintilă Ghițulescu, În șalvari și cu ișlic, 314-315.

61. Massino, Ambiguous Transition, 229.

62. The RCP officials named sexual harassment "immoral proposals." Br. Gh., a Party activist, was excluded from the RCP in 1951 for requesting sexual favors from women in exchange for employment. ANIC, fund CC of the RCP-CPC, file B/2867.

63. Ibid., file B/3567, 1 .

64. Ibid.

65. During state socialism, the Securitate was the political police, the Romanian equivalent of the ChEKA. In Soviet Russia, the ChEKA was considered an arm of the Party whose main goal was to defend the revolution. Richard Pipes, Scurtă istorie a revoluției ruse [A concise history of the Russian revolution] (Bucharest: Humanitas, 1998).

66. Report regarding the case of V. B. of 17 January 1959, ANIC, fund CC of the RCP-CPC, file $\mathrm{B} / 2577,3$.

67. Isabel Marcus, "Wife Beating: Ideology and Practice under State Socialism in Hungary, Poland, and Romania," Gender Politics and Everyday Life in State Socialist Eastern and Central Europe, ed. Shana Penn and Jill Massino (New York: Palgrave Macmillan, 2009), 116.

68. In articles 440 and 454, respectively. Codul Penal: Text oficial 1955, 470, 476.

69. Massino, Ambiguous Transition, 201, 228.

70. Report of Ploiești City Hall Organization of the RCP regarding the case of M. M. of 24 October 1959, ANIC, fund CC of the RCP-Cadre Department, file M/1684, 40.

71. ANIC, fund CC of the RCP-CPC, file B/3567, 1 .

72. Report concerning the case of V. B, ANIC, fund CC of the RCP-CPC, file B/2577, 3 .

73. Ibid.

74. The decision issued by the CPC concerning the case of M. B., of 4 February 1957, ANIC, fund CC of the RCP-CPC, file B/325, 4 .

75. Ibid.

76. According to the Romanian Penal Code, if the reconciliation between the victim and the perpetrator occurred, the criminal trial ceased. Article 481, Codul Penal al Republicii Populare Române adnotat, 1948, 517-518.

77. The decision issued by the CPC regarding the case of I. B., of 1 December 1956, ANIC, fund CC of the RCP-CPC, file B/1290, 3. 
78. Ibid.

79. In 1936, Corabia had 9,746 inhabitants. Dej had 15,311 inhabitants in 1930. Enciclopedia României [Encyclopedia of Romania], Vol. II: Țara Românească, ed. Dimitrie Gusti (Bucharest: Imprimeria Statului, 1938), 377, 413.

80. Report regarding the case of V. B. of 17 January 1959, ANIC, fund CC of the RCP-CPC, file $\mathrm{B} / 2577,3$.

81. A primary Party organization was the smallest unit of a Communist Party. According to the Party Statute of 1955, "The primary Party organizations are the Party's bedrock. The primary Party organizations are constituted in plants, agricultural enterprises, within the Army, in villages, state institutions, schools, universities, and other institutions with more than three Party members." "Statutul Partidului Muncitoresc Român," Scînteia, Friday, 30 December 1955, 4. Edward Cohn uses the same term: "primary Party organization." Cohn, "Disciplining the Party," 41, 65.

82. Jinga, Gen și reprezentare, 142.

83. Jinga, "Comrade First, Baba Second!", 75.

84. The decision of CPC of 14 December 1956 regarding I. B.'s appeal, ANIC, fund CC of the RCP-CPC, file B/1290, 3 .

85. E. Cohn's finding concerning the Soviet Union was also true for Romania: in practice, the meetings could be poorly planned and subject to the whim of the people involved. Cohn, "Disciplining the Party," 49.

86. Minute of the extraordinary meeting of the general assembly of the RCP primary organization of Ploiești City Hall, 26 October 1959, ANIC, fund CC of the RCP-Cadre Department, file $\mathrm{M} / 1684,40$.

87. Ibid., 94.

88. Ibid., 93.

89. Massino, Ambiguous Transition, 30n49.

90. Minute of the extraordinary meeting of the general assembly of the RCP primary organization of Ploiești City Hall, 26 October 1959, ANIC, fund CC of the RCP-Cadre Department, file $\mathrm{M} / 1684,93$.

91. Ibid., 95.

92. ANIC, fund CC of the RCP-CPC, file B/3567, 1 .

93. Jinga, Gen și reprezentare, 143.

94. The decision of CPC of 14 December 1956 regarding I. B.'s appeal, ANIC, fund CC of the RCP-CPC, file B/1290, 3 .

95. Art. 13-17, Statutul Partidului Muncitoresc Român, 1948, 10; Art. 10-15, "Statutul Partidului Muncitoresc Român," Scînteia, Friday 30 December 1955, 3.

96. Report regarding the case of V. B. of 17 January 1959, ANIC, fund CC of the RCP-CPC, file $\mathrm{B} / 2577,3$. 